\title{
Intertidal zonation among congeners: factors regulating distribution of porcelain crabs Petrolisthes spp. (Anomura: Porcellanidae)
}

\author{
Gregory C. Jensen, David A. Armstrong \\ School of Fisheries WH-10, University of Washington, Seattle, Washington 98195, USA
}

\begin{abstract}
The porcelain crabs Petrolisthes cinctipes (Randall) and P. eriomerus Stimpson are sympatric on exposed rocky shores in the northeastern Pacific. These species often exhibit a striking pattern of non-overlapping vertical distributions, with $P$. eriomerus inhabiting low intertidal and subtidal areas and $P$. cinctipes occurring in the middle and high intertidal. Transplant experiments revealed that $P$. eriomerus was unable to tolerate displacement as little as $0.3 \mathrm{~m}$ above its normal limit, while in contrast its congener showed good survival and growth when caged at lower levels. The 2 species were equally susceptible to desiccation; however, $P$. eriomerus was extremely sensitive to thermal stress during periods of aerial exposure, and thermal tolerance varied inversely with size. Abiotic factors also control the distribution of $P$. cinctipes; this species was competitively dominant in laboratory experiments, suggesting the lower limit is not due to interactions with its congener. Rather, this distribution is linked to sudden changes in substrate composition, involving an active avoidance of rocks resting on sand or silt as demonstrated through field manipulation of substrate beneath rock patches. Patterns of resource (space) partitioning beneath rocks are largely a passive consequence of physiological constraints and substrate preferences by adults, maintained in part through gregarious settlement by megalopae of both species.
\end{abstract}

\section{INTRODUCTION}

Patterns of intertidal zonation have long intrigued marine ecologists, and there is a considerable body of work documenting the factors responsible for the vertical distribution of intertidal organisms. A general trend is a tendency for the upper limit of species to be determined by physical perturbations of the environment (e.g. desiccation, thermal stress) while lower limits are often the result of biotic interactions, such as competition and predation (Connell 1961). The majority of this work has dealt with sessile species (barnacles, mussels, algae), with few studies on motile organisms which, while less amenable to experimental manipulation, can also exhibit striking patterns.

Among the motile groups that have received little attention are the decapod Crustacea, with most studies to date dealing with physiological and morphological adaptations related to aerial exposure. Gray (1957) examined the gill morphology of brachyurans and found trends toward increasing scleratization and decreasing gill area at higher tide levels, and Hiatt (1948) noted similar reductions in gill volume. Smaller, firmer gills presumably retain their shape and thus function better out of water, and in some species interlamellar cross-bridges apparently serve to maintain spacing between surfaces during aerial exposure (Johnson \& Uglow 1985). Herreid (1969b) showed that the exoskeleton of upper intertidal brachyuran crabs is highly impermeable to water vapor compared to that of low intertidal or subtidal species. Considerable attention has also been directed toward the physiological consequences of aerial exposure, especially various aspects of blood chemistry and respiration (Truchot 1975, deFur et al. 1983, dePledge 1984, Burnett 1988, deFur 1988). Yet comparative studies are often conducted on crabs of different genera or families, sometimes even from entirely different geographic locations (e.g. Burggren \& McMahon 1981, Johnson \& Uglow 1985, Burnett \& McMahon 1987). Comparisons of closely related sympatric species in order to explain small-scale differences in vertical zonation have been lacking

Although many examples of zonation among sympatric congeners have been described for intertidal decapods (Teal 1958, Jones 1972, Iceley \& Jones 1978, 
Abrams 1987, Menendez 1987) little is known of the ecological, physiological, or behavioral mechanisms responsible for the establishment and maintenance of these patterns. Most work to date has been with assemblages of fiddler crabs, Uca spp., in studies on distribution correlated with single abiotic factors such as sediment composition (Iceley \& Jones 1978) or temperature (Edney 1961, Macintosh 1978). An early study (Teal 1958) that incorporated aspects of both behavior and physiology provided evidence that differing salinity tolerances, substrate preferences, and competitive interactions all influenced the distribution of 3 species of $U_{C a}$ in a Georgia salt marsh.

In one of few field manipulations addressing biotic interactions in regard to decapod zonation, Nyblade (1974) entirely removed the middle species in an assemblage of vertically separated intertidal hermit crabs. With the middle species absent there was no evidence of movement into the area by either the 2 higher or 3 lower species, and he concluded that there was minimal interspecific competition for habitat.
Other field manipulations have dealt with mechanisms restricting a single species to a particular level. Posey (1986) demonstrated that the lower limit of Callianassa californiensis is due to predation by the staghorn sculpin Leptocottus armatus, and Engstrom (1984) found indications that predation by bonefish restricts the vertical distribution of a xanthid crab. For the most part, however, investigations into zonation have emphasized physiological tolerances or substrate differences rather than biotic interactions. Sampling within different levels almost invariably reveals differences in the physical environment (mean grain size, temperature, etc.), but does not demonstrate that these factors are responsible for the observed distribution. Only when such information is used in conjunction with manipulative experiments can the underlying cause of the zona tion be determined.

Observations of the porcelain crabs Petrolisthes cinctipes and $P$. eriomerus on the outer coast of Washington State and British Columbia indicated a striking pattern of intertidal zonation in which the 2 species occupy the
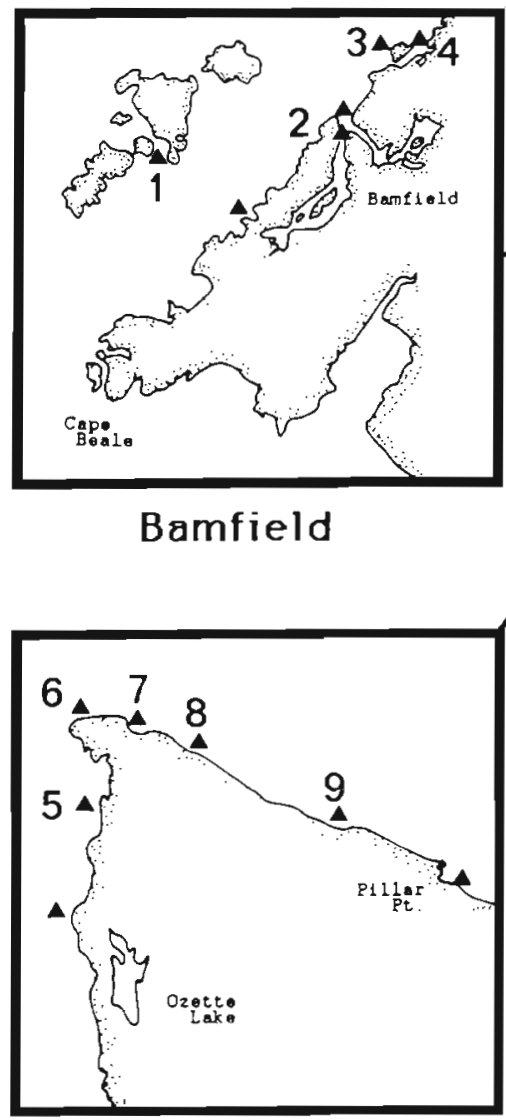

Neah Bay

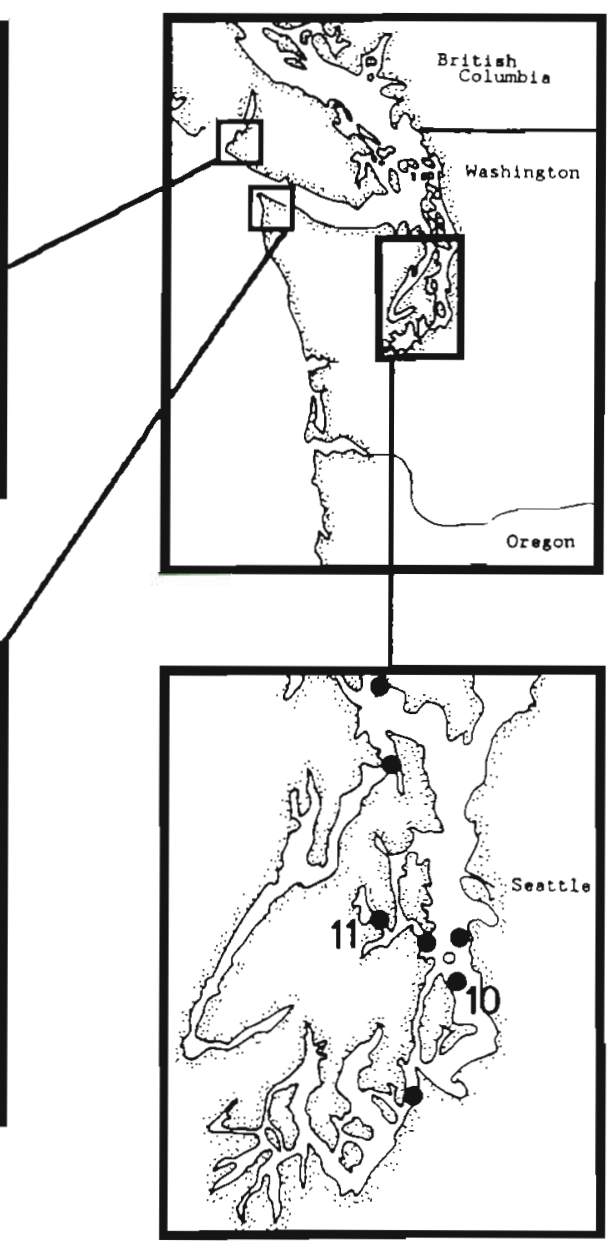

Puget Sound
Fig. 1 Lacation of study sites in the northeastern Pacific. (•) Beaches where only Petrolisthes eriomerus was found: $(\Lambda)$ beaches where both $P$. eriomerus and $P$. cinctipes occur. (1) Diana Island (2) Bamfield Marine Station, (3) Dixon Island, (4) Kelp Bay, (5) Shi Sh, (6) Cape Flattery, (7) Neah Bay jetty, (8) Neah Bay site, (9) Clallam Bay, (10) Vashon Island, (11) Bremerton 
mid- to upper and lower intertidal areas, respectively (Zitten 1979, Jensen 1990). Gregarious settlement by megalopae of these 2 species (Jensen 1989) helps to maintain the existing zonation pattern, but fails to explain what restricts the highly motile adults to a particular level. After quantitative sampling to further document the zonation patterns in different areas, a series of laboratory experiments and field manipulations were conducted in an attempt to isolate the factors involved in the establishment of this pattern.

\section{MATERIALS AND METHODS}

Sampling. Quantitative sampling was conducted at several locations in Washington State, USA (Fig. 1) During extreme low tides, transect lines were placed at randomly selected points on the beach, extending from the water's edge to the upper intertidal. Rocks along the line were removed and placed upside-down in a plastic dishpan to retain small instars and megalopae clinging to the underside, and the remaining crabs collected by hand and measured to the nearest $0.1 \mathrm{~mm}$ carapace width (cw).

The tidal level of rocks sampled for crab was determined by noting the time when the incoming tide first reached the level of a sampled rock, then calculating the height at each time using published tables (NOAA 1989). Measurements obtained by this method closely agreed with those using a surveyor's level, with the added advantage of not requiring a second person. On short, steep beaches, 2 measuring sticks connected by a clear piece of flexible tubing filled with water were used to measure the absolute height difference between locations. For consistency, Canadian tide heights (MLLWLT) were converted to a rough equivalent of mean lower low water (MLLW) by subtracting 0.76 m (NOAA 1989).

Qualitative observations of porcelain crab distributions were made at a number of other sites within Washington State and on Vancouver Island near Bamfield, British Columbia, Canada (Fig. 1). Upper and lower limits of Petrolisthes eriomerus and $P$. cinctipes were noted, respectively, and tide heights determined by the methods described above.

Transplant experiments. Cages constructed of plastic screen (6.4 mm mesh, Norplex, Inc.) and containing a circular concrete patio block $(30.5 \mathrm{~cm}$ diameter) were placed at the $0.0 \mathrm{~m}$ and $+1.2 \mathrm{~m}$ tide levels near Neah Bay, Washington, on 26 June 1987. Six cages were placed at each level, each containing 16 adult crabs ( 8 male, 8 female; $>9 \mathrm{~mm} \mathrm{cw}$ ), with 3 of the cages containing Petrolisthes cinctipes and 3 with $P$. eriomerus. Cages were inspected 1 mo later and the number of surviving crabs counted.
A second transplant experiment compared growth rates of juvenile Petrolisthes cinctipes caged within their usual tidal range (controls) to ones caged within the lower zone inhabited by $P$. eriomerus. Ten mesh bags, constructed from 900 um nylon mesh (Nytex, Inc.) and containing a single rock and $12 P$. cinctipes megalopae, were placed on the beach at Diana Island (Fig. 1) on 12 August 1988. Five 'low' cages were placed at the $-0.5 \mathrm{~m}$ tide level, and 5 'high' at $+0.7 \mathrm{~m}$. These were retrieved on 25 September 1988 and all specimens measured to $0.1 \mathrm{~mm} \mathrm{cw}$, using a dissecting scope equipped with an ocular micrometer. At this time the bags were replaced by more durable containers made from large diameter PVC pipe and $1.0 \mathrm{~mm}$ screen, each containing a piece of concrete brick. The original megalopae (now juveniles) were placed inside and the cages again deployed at the same 2 levels Cages were again checked and juveniles measured on 9 April and 18 July 1989.

Desiccation experiment. Ten adults each of Petrolisthes cinctipes and $P$. eriomerus within a similar size range were measured, uniformly blotted, individually placed in tared plastic vials and weighed to the nearest $0.1 \mathrm{mg}$ on an electrobalance. Trays of vials (with the 2 species interspersed) were placed uncovered in an incubator at $10^{\circ} \mathrm{C}$; every hour the trays were removed and the individual vials weighed until all crabs had expired. Since water loss is by far the most important component of weight loss during short periods of aerial exposure (Herreid 1969a), all changes in weight were considered to be due to water lost through evaporation. Relative humidity within the chamber was not controlled but was checked each hour with a hygrometer, and remained at $53 \%$ throughout the duration of the experiment. At each weighing the crabs were checked for responses, and were considered dead when there were no visible responses to touch and mouthparts were limp. After death all specimens were dried to constant weight in tared aluminum pans at $50^{\circ} \mathrm{C}$ and weighed. Percentages of body water lost (Young 1978) were arcsine transformed for statistical comparisons; survival times were compared using the Mann-Whitney test.

Thermal stress experiment. Twelve specimens each of Petrolisthes cinctipes and P. eriomerus were measured, blotted, weighed, and individually placed in covered plastic petri dishes containing a piece of filter paper saturated with seawater. Four dishes containing each species were placed in incubators at 15, 20, and $25^{\circ} \mathrm{C}$, and the crabs were checked every $0.5 \mathrm{~h}$ for response as described above. Since preliminary tests suggested a relationship between size and survival in $P$. eriomerus, a second experiment was conducted at $25^{\circ} \mathrm{C}$ with crabs ranging in size from 2.3 to $13.7 \mathrm{~mm} \mathrm{cw}$ $(\mathrm{n}=31)$. The 2 experiments were terminated after 24 and $25 \mathrm{~h}$, respectively. 
Thermal tolerance of immersed specimens was also tested at $25^{\circ} \mathrm{C}$. Five specimens of Petrolisthes eriomerus ( 7.9 to $13.3 \mathrm{~mm} \mathrm{cw}$ ) and $3 P$. cinctipes (10.6 to $16.6 \mathrm{~mm} \mathrm{cw})$ were placed in uncovered glass preparation dishes that were submerged in a common bath kept well aerated by 2 pumps equipped with airstones. The experiment was conducted inside an incubator and the crabs checked hourly for a period of $24 \mathrm{~h}$.

Competition experiments. Two types of competition experiment were run at the Bamfield Marine Station. The first was conducted in a glass aquarium supplied with unfiltered seawater, using 10 large adults of each species ( 5 male, 5 female; $>10 \mathrm{~mm} \mathrm{cw}$ ). Each specimen used was within $0.2 \mathrm{~mm} \mathrm{cw}$ of a congener of the same sex in the other group, and each group was allowed $24 \mathrm{~h}$ to become established beneath bricks on either side of a larger, elevated concrete block in the center of the aquarium over which incoming water was directed. At this time a barrier separating Petrolisthes eriomerus from the underside of the central block was lifted, and they were allowed $24 \mathrm{~h}$ to become established before a second barrier was lifted allowing entry of $P$. cinctipes into the same space. Initial interactions between the species were viewed using a mirror below the tank, and their respective positions followed for the next 2 to $3 \mathrm{~d}$. Three runs were made, each using new crabs and alternating starting positions.

The second experiment compared the ability of Petrolisthes cinctipes and $P$. eriomerus to win space from previously established $P$. eriomerus on a sand substrate. Fine sediments appeared more prevalent within the tidal levels inhabited by $P$. eriomerus, and it was possible this species could have a competitive advantage under such conditions. A single square slate plate was placed directly on the surface of the sand in each of 8 white buckets continuously supplied with unfiltered seawater. Ten adult $P$. eriomerus $(2$ between 8.0 and $9.9 \mathrm{~mm} \mathrm{cw}, 6$ from 10 to $11.9 \mathrm{~mm}$, and 2 from 12 to $13.9 \mathrm{~mm}$; 5 of each sex) were added to each and allowed $48 \mathrm{~h}$ to excavate beneath the plates before 10 $P$. cinctipes or $P$. eriomerus of the same size composition were added; 'new' $P$. eriomerus were tagged with small pieces of white plastic glued to the carapace with cyanoacrylate adhesive so that they could be distinguished from 'resident' crabs. The number and type of crabs lacking shelter was recorded each morning for the following $4 \mathrm{~d}$.

Sediment sampling. Sediment samples were collected from 5 beaches: near Neah Bay; at Dixon Island and on the shore across from Dixon Island; and at Kelp Bay and the Bamfield Marine Station foreshore (Fig. 1). The first 3 areas were selected after extensive surveys indicated the zonation patterns at these locations were representative of the outer Washington coast and the Bamfield region, respectively. The latter 2 beaches were sampled because they were the only locations found that did not exhibit the usual vertical separation of the 2 species, in hope that comparison with typical beaches might reveal the cause of the pattern. Samples were taken only from beneath rocks with large populations of Petrolisthes spp. present; any material in contact with or facing the bottom of the rock (other rocks, shell) and/or the top $-1 \mathrm{~cm}$ of finer sediments was collected with a garden trowel. All samples were ovendried, hand-shaken through a series of sieves, weighed, and the percentage of different grain size fractions calculated. The standard Wentworth grade of classification was divided into 3 major categories: pebble-cobble ( 4 to $256 \mathrm{~mm}$ ), coarse sand-granule $(500 \mu \mathrm{m}$ to $4 \mathrm{~mm})$, and silt-medium sand $(62 \mu \mathrm{m}$ to $500 \mu \mathrm{m})$.

Selection experiment. Six elongate patches of rock were placed on the beach at Dixon Island after removing all rocks and crabs from the area. These patches of habitat were of equal dimensions $(4.3 \times 0.6 \mathrm{~m}$ and $\sim 1 \mathrm{~m}$ apart) and tide height, and positioned so that the midpoint of each patch corresponded to the level separating the 2 species. All rocks within each patch were placed at the same tide level as their original location, thus retaining the natural zonation of attached organisms. Control patches rested on the existing substrate, while in the interspersed treatments the natural sediment (primarily sand) from the lower half of the patch was excavated and replaced with concrete patio blocks at ground level; the patch rocks were then placed on top of the concrete (Fig. 2). Each patch was divided into 10 equal sections, and 10 tagged adult Petrolisthes cinctipes were added to each section (total of 600 tagged crabs). Tags were made by laser-printing

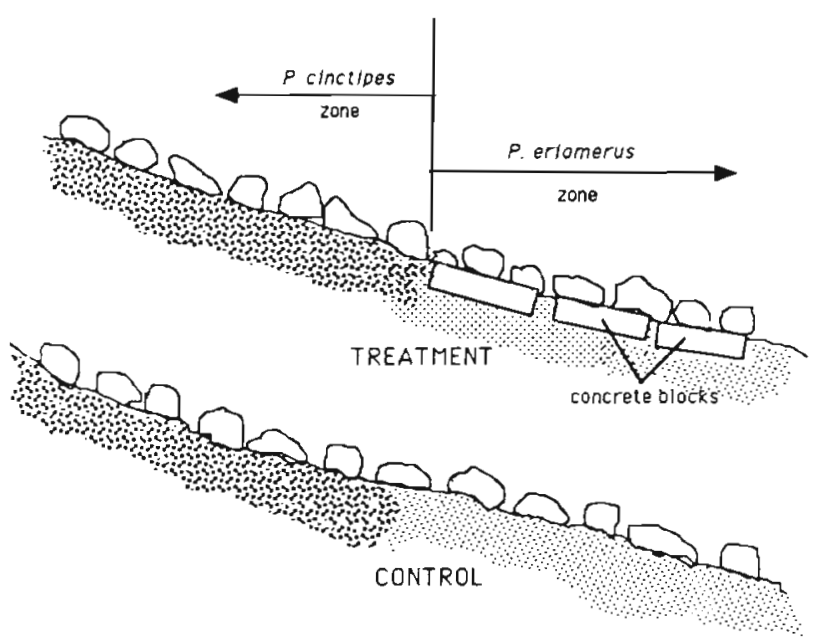

Fig. 2. Diagrammatic side view of treatment and control patches used in the substrate selection experiment for $P e$ trolisthes cinctipes. Rock patches were placed perpendicular to the water's edge, and existing sediment replaced with concrete blocks in the lower half of the treatment patches 
numbers on acetate film and then laminating clear plastic tape over the sheet; the labels were then punched out and attached to the carapace of the crabs with cyanoacrylate adhesive. The tag code identified the section and rock patch where each crab was added. After approximately 1 mo (14 December 1989 to 9 January 1990) all remaining crabs were collected from each rock patch and their position noted.

\section{RESULTS}

\section{Sampling}

A distinct separation of the species was apparent at approximately the $+0.8 \mathrm{~m}$ tidal level, and neither population showed any segregation by size or sex even at the borderline of their distributions (e.g. Neah Bay and Clallam Bay, Fig. 3). The upper limit of Petrolisthes eriomerus at these locations corresponds to that observed on the sheltered side of the Neah Bay jetty, an area subject to the same tidal regime but where $P$. cinctipes is
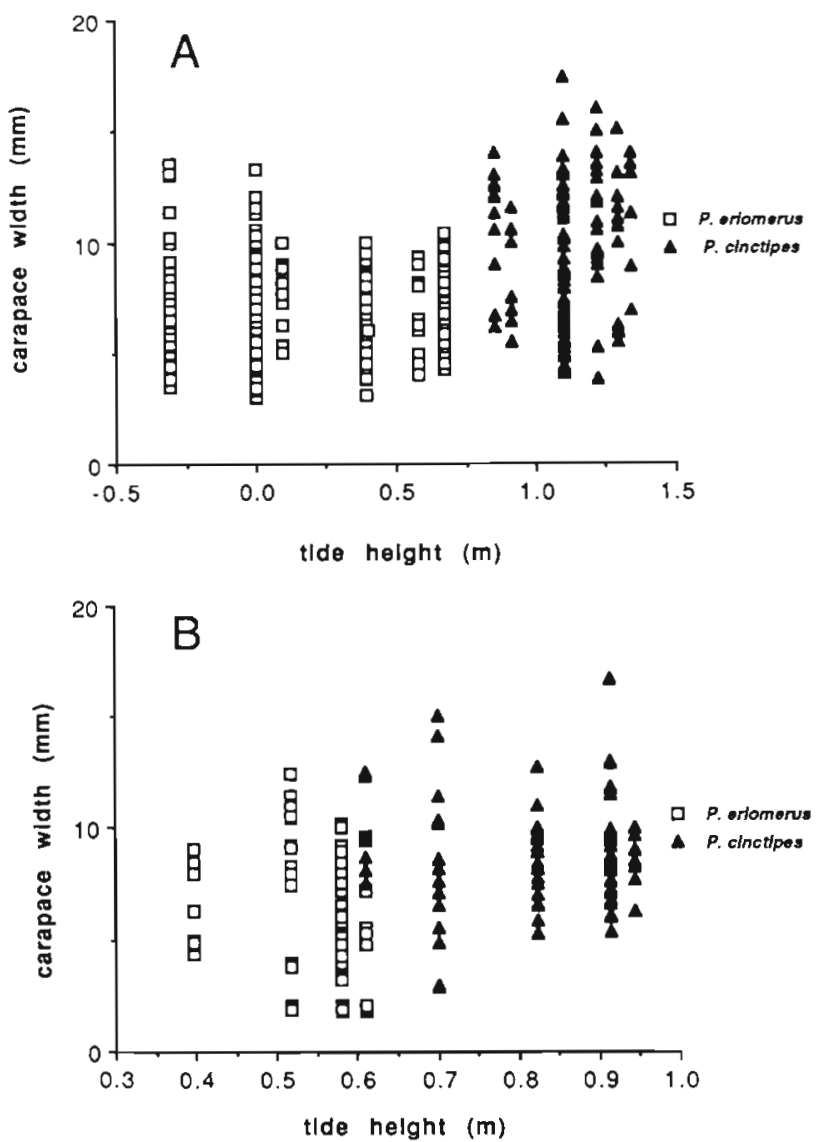

Fig. 3. Petrolisthes spp. Vertical distribution at (A) Neah Bay and (B) Clallam Bay
Table 1 Petrolisthes eriomerus and $P$. cinctipes. Upper and lower limits of Petrolisthes eriomerus and $P$. cinctipes, respectively, at locations in Washington, USA, and British Columbia, Canada. Values are in $\mathrm{m}$ above or below mean lower low water. See Fig. 1 for locations

\begin{tabular}{|lcc|}
\hline Location & $\begin{array}{c}\text { P. eriomerus, } \\
\text { upper limit }\end{array}$ & $\begin{array}{c}\text { P. cinctipes, } \\
\text { lower limit }\end{array}$ \\
\hline Clallam Bay & +0.6 & +0.6 \\
Neah Bay & +0.6 & +0.6 \\
Vashon Island & -0.1 & Absent \\
Bremerton & -0.1 & Absent \\
Diana Island & +0.1 & -0.1 \\
\hline
\end{tabular}

absent (only 1 specimen was found in several hours of searching). Inside Puget Sound, the upper limit of $P$. eriomerus is near the $-0.1 \mathrm{~m}$ tide level (Table 1 ), while at Diana Island it occurs up to $+0.1 \mathrm{~m}$. The upper limit of $P$. cinctipes was approximately $+1.5 \mathrm{~m}$ at Neah Bay and Clallam Bay, and $+2.0 \mathrm{~m}$ in Barkley Sound.

\section{Transplant experiments}

All Petrolisthes cinctipes and $P$. eriomerus caged at the lower level $(0.0 \mathrm{~m})$ were recovered alive, while none of the $P$. eriomerus that had been placed in the upper level $(+1.2 \mathrm{~m})$ survived the $30 \mathrm{~d}$ of the experiment. All $P$. cinctipes within 2 of the upper-level cages survived but the third cage was dislodged by waves and rolled about, crushing many crabs and resulting in high $(75 \%)$ mortality.

Petrolisthes cinctipes megalopae caged at the 2 levels showed no apparent difference in size after $1 \mathrm{yr}$ (Fig. 4); however, the loss of containers throughout the year resulted in too few replicates for statistical com-

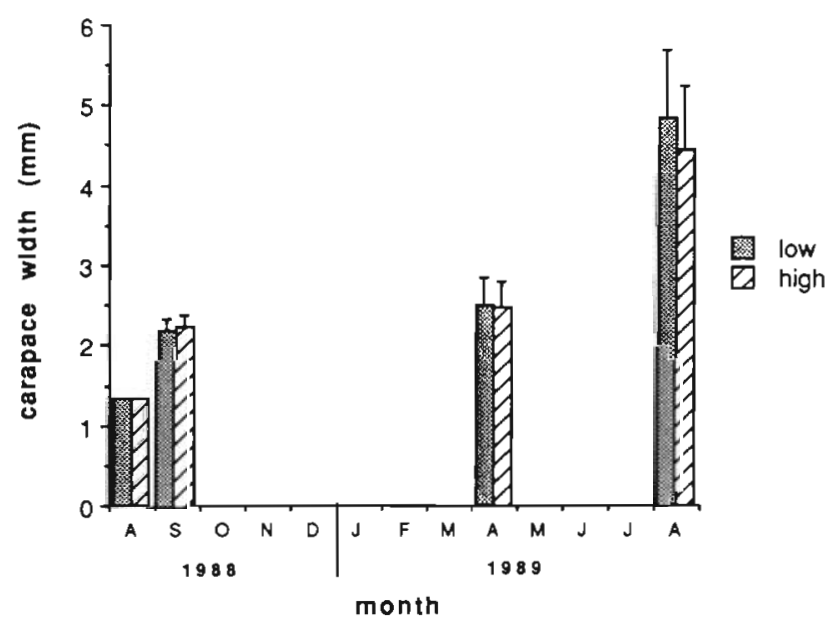

Fig. 4. Petrolisthes cinctipes. Growth of megalopae and juveniles in low $(-0.5 \mathrm{~m}$, below mean lower low water) and high $(+0.7 \mathrm{~m})$ cages at Diana Island. Capped bars represent $1 \mathrm{SD}$ 

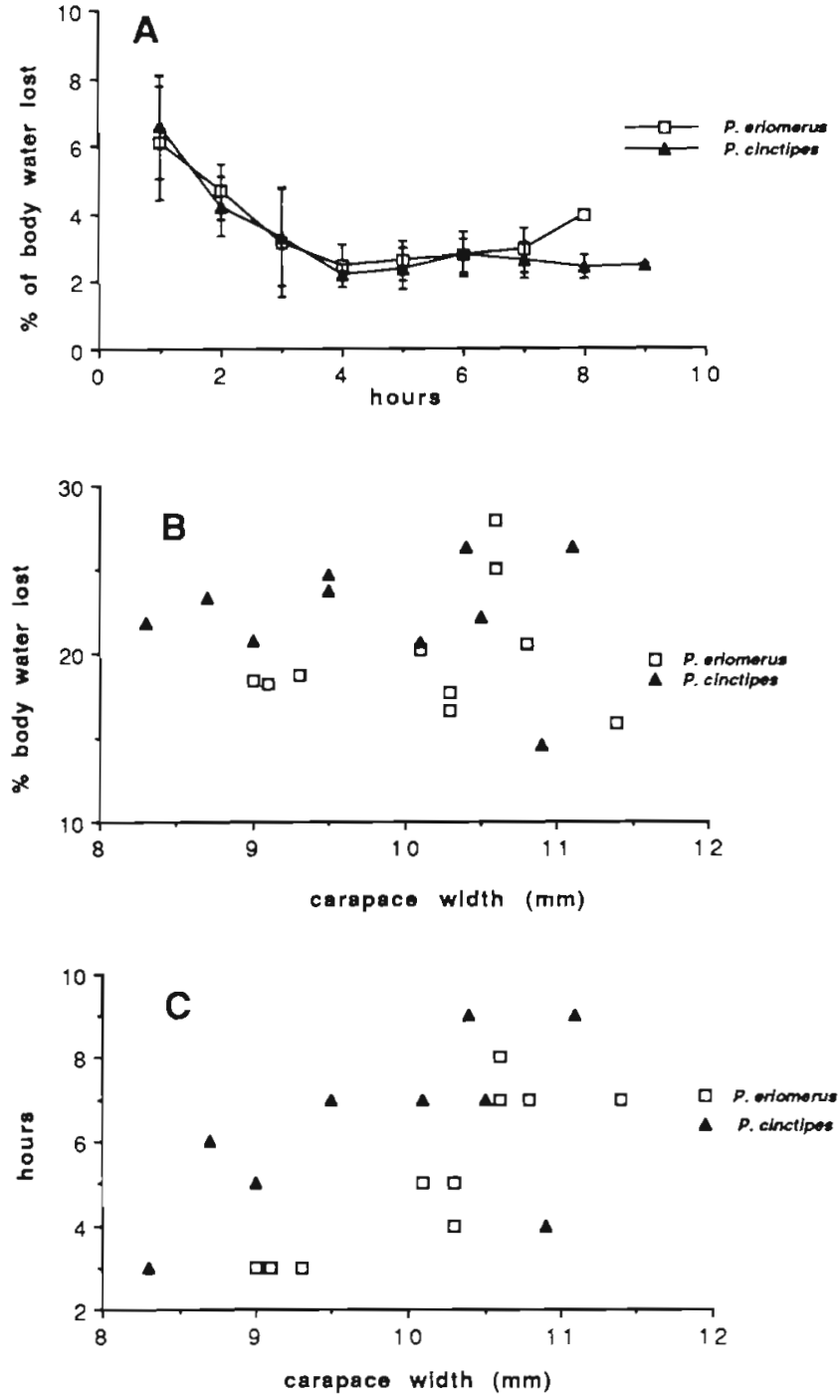

Fig. 5. Petrolisthes spp. Desiccation experiment. (A) Rates of body water loss; bars represent $1 \mathrm{SD}$. (B) Total percentage of body water lost at death. (C) Survival time and size

parison (only 1 high and 2 low treatments remained at the end). Instars grew very little over winter; many were molting when checked in late September and apparently did not molt again until sometime after early April the following year.

\section{Desiccation experiment}

No significant differences were found either in rate of water loss by the 2 species (Fig. $5 \mathrm{~A}$; $t$-test, $p>0.10$ ) or in percentage of total body water lost at death (Fig. $5 B$; $t$-test, $\mathrm{p}>0.30$ ). Although Petrolisthes cinctipes tended to live slightly longer (Fig. 5C), this difference was far too small to account for the great differences in distribution of the 2 species.

\section{Thermal stress experiment}

Both species survived in air for $24 \mathrm{~h}$ at $15^{\circ} \mathrm{C}$, but at $20^{\circ} \mathrm{C}$ Petrolisthes eriomerus survived an average of 5.5 ( $\pm 1.73, \mathrm{SD}) \mathrm{h}$ and just $2.25( \pm 0.96) \mathrm{h}$ at $25^{\circ} \mathrm{C}$ (Fig. 6). Body weight at death was unchanged, indicating that death was not due to desiccation. In sharp contrast, all $P$. cinctipes survived $24 \mathrm{~h}$ at these higher temperatures with no visible distress. The sensitivity of $P$. eriomerus to the highest temperature was very size-specific, with large adults surviving less than $0.5 \mathrm{~h}$ while the smallest crab tested ( $2.2 \mathrm{~mm} \mathrm{cw}$ ) was still alive when the experiment was terminated at $25 \mathrm{~h} \mathrm{(Fig.} \mathrm{7).} \mathrm{In} \mathrm{the} \mathrm{immersion}$ experiment all specimens of both species survived for $24 \mathrm{~h}$ at $25^{\circ} \mathrm{C}$ with no visible signs of distress.

\section{Competition experiments}

Prior to removal of the barriers, 1 of the larger males of each species had established dominance over all

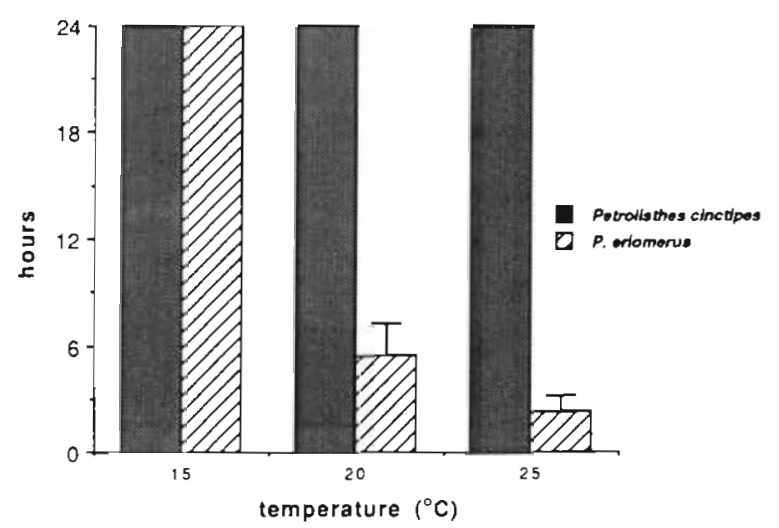

Fig. 6. Petrolisthes spp. Thermal stress experiment. Mean survival times for 4 specimens each of $P$. cinctipes and $P$. eriomerus at 15,20 , and $25^{\circ} \mathrm{C}$; experiment terminated after $24 \mathrm{~h}$

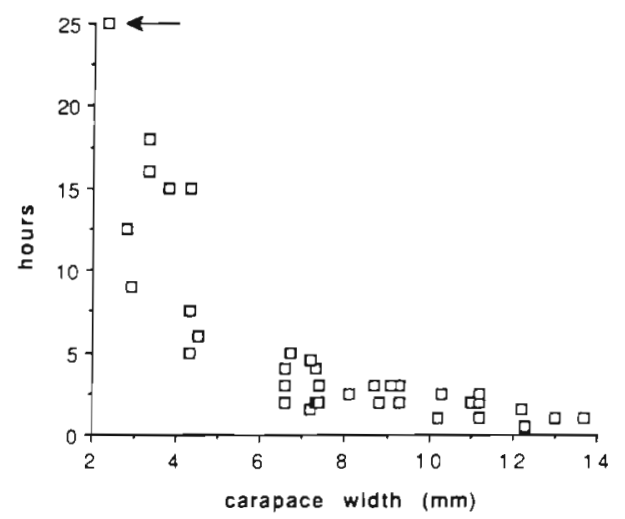

Fig. 7. Petrolisthes eriomerus. Effect of size on survival at $25^{\circ} \mathrm{C}$. Smallest specimen (arrow) appeared healthy when experiment was terminated at $25 \mathrm{~h}$ 


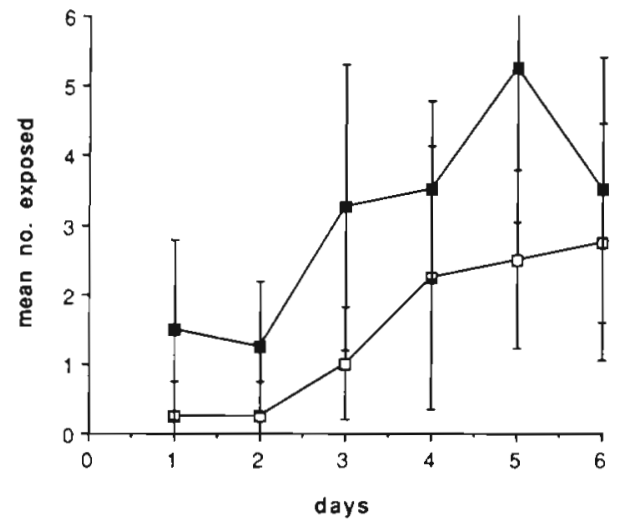

Fig. 8. Petrolisthes eriomerus. Number of 'resident' crabs left exposed in presence of $(\mathbf{a})$ added $P$. cinctipes or $(\square)$ added conspecifics. The new crabs were added on Day 2; bars represent $1 \mathrm{SD}$

crabs within its section. These dominant males initially roamed about the underside of the bricks, attacking other crabs regardless of sex and driving them from the area. After several hours the dominant male gradually became more tolerant of other crabs, and as the frequency and violence of attacks subsided the subordinate crabs tended to remain on the undersurface of the block. At this point the behavior of the 2 species began to differ, with large subordinate male Petrolisthes cinctipes continuing to use the underside of the block while defeated male $P$. eriomerus tended to avoid the underside of the block entirely.

When the first barrier was removed the dominant male Petrolisthes eriomerus moved to the central section and began feeding passively in the incoming water. Females and some males also moved into this area, while larger subordinate males remained exposed on the sides of the bricks or huddled in corners of the tank. Removal of the second barrier to allow access to the central area by $P$. cinctipes resulted in a dramatic change in the distribution of $P$. eriomerus. As $P$. cinctipes began to explore the central area, subordinate male and female $P$. eriomerus generally moved aside without offering resistance. In each case the dominant $P$. cinctipes was the first to explore the new area, and in all 3 runs it displaced the dominant $P$. eriomerus form the area in front of the incoming water. In 1 run a dominant $P$. eriomerus vigorously attacked the dominant $P$. cinctipes 3 times, grasping at its chelipeds but each time being driven backwards by a sudden, simultaneous outward push of the chelipeds ('chela shove', Molenock 1976). Within 24 h of mixing the area near the incoming water was populated only with male $P$. cinctipes, while females and both sexes of $P$. eriomerus were found farther 'downstream' or within the side sections. Inter- and intraspecific fights were almost non-existent by this time.

In the experiment where a sand substrate was used, there was no significant difference after $4 \mathrm{~d}$ in the average number of 'resident' Petrolisthes eriomerus that had lost their shelter to conspecifics or congeners (Fig. 8) or in the number of new crabs that had won space under the plate. Crabs without shelter were often seen attempting to dislodge those under the slate plates, but no successful attacks were observed.
Fig. 9. Composition of sediment beneath rocks inhabited by porcelain crabs Petrolisthes spp. at the Neah Bay site

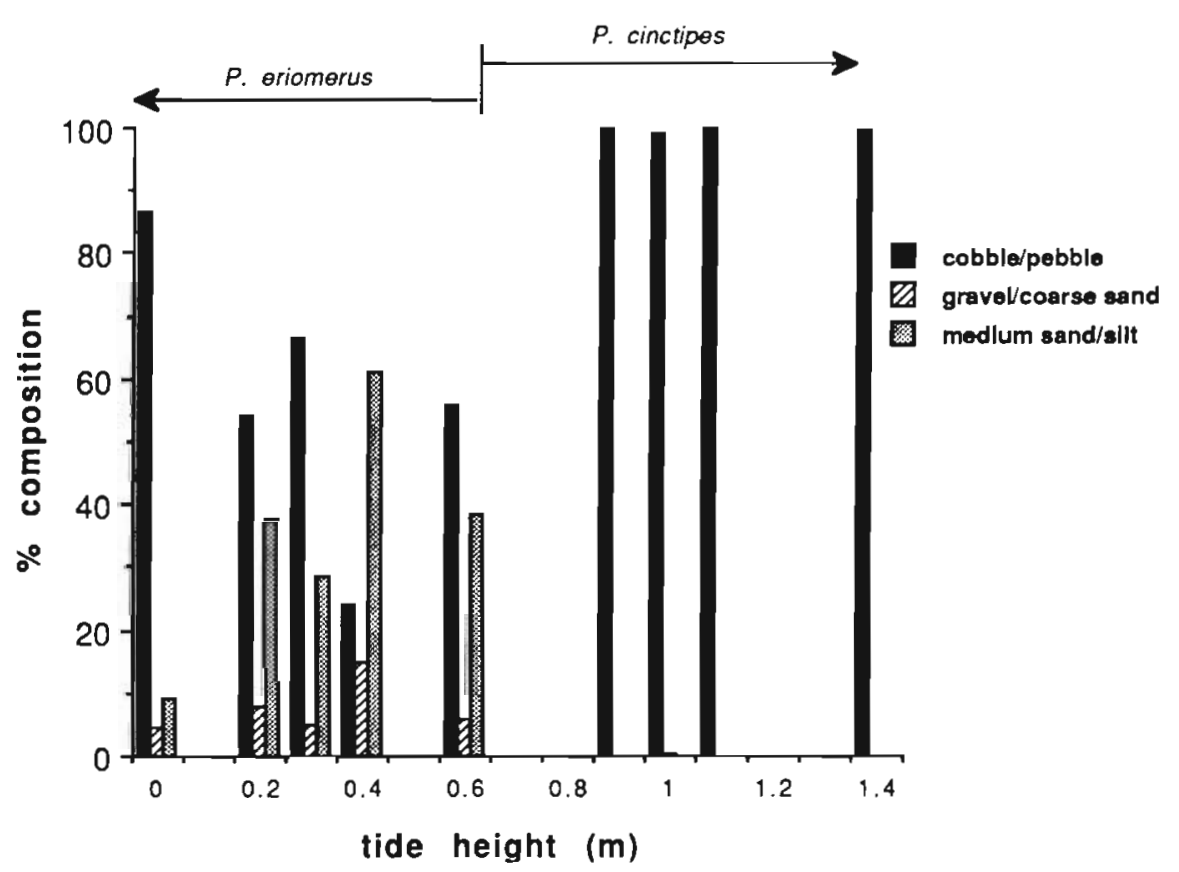



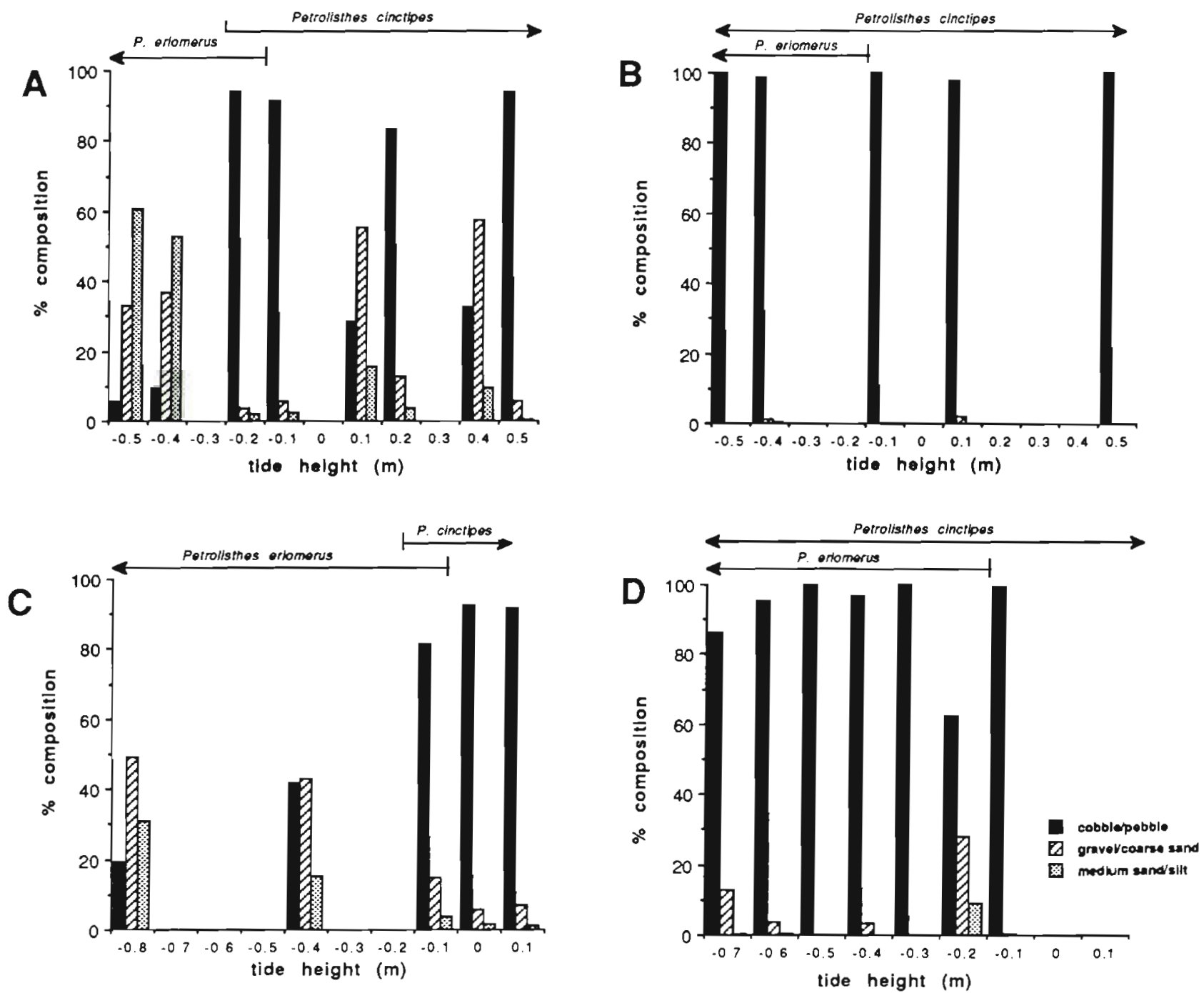

Fig. 10. Sediment composition beneath rocks used by porcelain crabs Petrolisthes spp.; arrows indicate distribution of the 2 species for each lacation. (A) Channel shoreline facing Dixon Island; (B) Kelp Bay; (C) Dixon Island; (D) Bamfield Marine Station foreshore

\section{Sediment sampling}

The distribution of Petrolisthes cinctipes was strongly correlated with the composition of the substrate under the rocks. The striking zonation pattern at the Neah Bay site (Fig. 3A) matches a similar extreme change in composition of the sediment (Fig. 9); in the lower zone rocks tended to be partially embedded in sand or silt but rested on a pebble/cobble bed in the upper zone. At Dixon Island and on the beach facing Dixon Island there was a slight overlap in the vertical distribution of the 2 species, but again the lower limit of $P$. cinctipes coincided with an increased fraction (>20\%) of finer sediments (Fig. 10A, C). In contrast, the Bamfield Marine Station foreshore had almost no sand (Fig. 10D) and $P$. cinctipes was found throughout the entire intertidal, extending at least $0.8 \mathrm{~m}$ below its usual level on beaches in the area. At Kelp Bay, a natural beach similar to the station foreshore, $P$. cinctipes has also extended its distribution for lower into the intertidal than on nearby beaches (Fig. 10B), and again sand was absent. The highest proportion of sand under a rock populated with $P$. cinctipes was $15.7 \%$ but was generally much lower $(\overrightarrow{\mathrm{x}}=1.8 \%)$; in contrast the distribution of $P$. eriomerus appeared to be related only to tide height, irrespective of substrate composition. Fig 11 summarizes the results of the sediment analysis. Most samples $(20$ of 30$)$ from rocks inhabited by $P$. cinctipes only had $>95 \%$ cobble/pebble, so for clarity many were not included. 


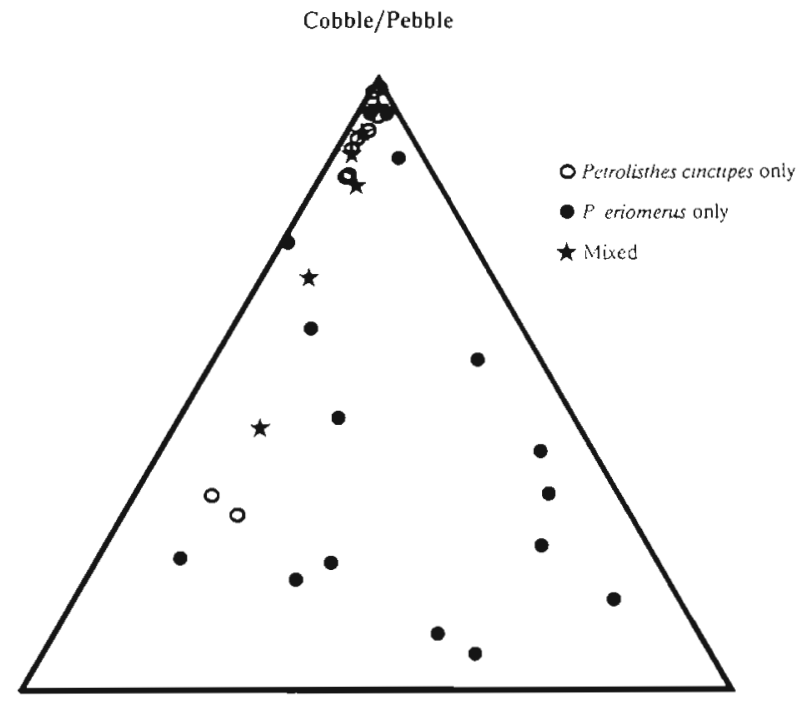

Gravel/Coarse Sand

Medium Sand/Silt

Fig. 11 Composition of substrate collected beneath rocks inhabited by porcelain crabs Petrolisthes spp. For the sake of clarity, 18 open circles ( $P$. cinctipes only) are not included, since all were composed of $>95 \%$ cobble/pebble

\section{Selection experiment}

A total of 258 tagged crabs were recovered within the habitat patches, and another 90 were found under rocks outside the experimental area. The distribution of Petrolisthes cinctipes within treatment and control patches differed dramatically (Fig. 12). Crabs were virtually absent from the lower half of the controls ( $\bar{x}=$ $2.3 \pm 1.5$ ), while the lower half of treatment patches

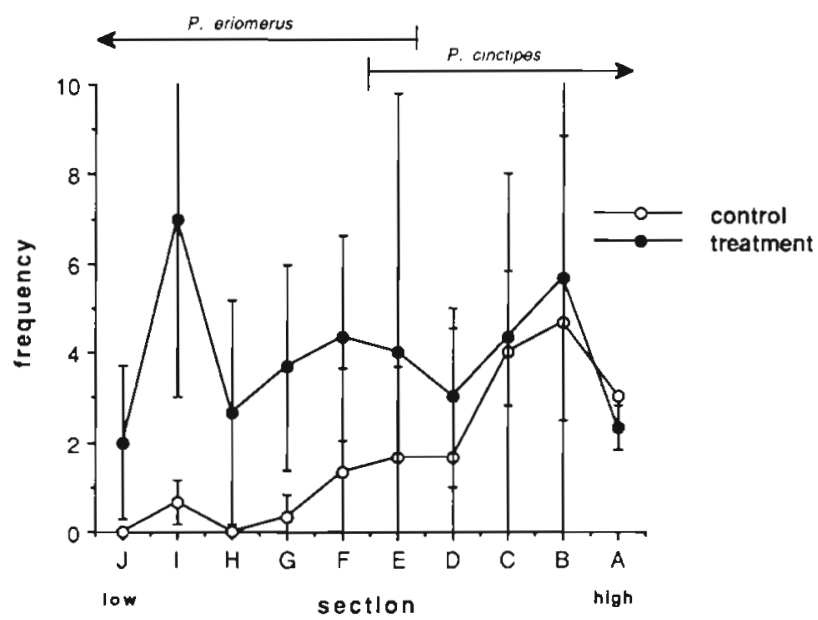

Fig. 12. Petrolisthes cinctipes. Distribution of crabs recovered within the same rock piles where they were released. Values are means for 3 replicates; bars represent $1 \mathrm{SD}$. Arrows at top indicate natural zonation of the 2 Petrolisthes species in that location prior to the experiment was still occupied by many $P$. cinctipes $(\overline{\mathrm{x}}=19.7 \pm 5.0$; t-test, $0.0025>\mathrm{p}>0.001$ ). Crabs that remained in control patches moved up the tidal gradient an average of $1.84( \pm 2.7)$ sections, compared to a mean net displacement in the treatments of $-0.24( \pm 2.4)$ sections. Significantly more crabs remained within 1 section of their starting point in treatment patches $(\dot{x}=24.7 \pm 3.2)$ than in controls $(\bar{x}=8.0 \pm 2.0)$. Only 10 crabs placed in treatment patches moved into controls, compared to 60 moving the other way.

\section{DISCUSSION}

The sampling results confirmed initial observations of vertical separation of the 2 Petrolisthes species, and particularly striking was the failure of $P$. eriomerus to exploit higher levels on the beach when $P$. cinctipes was absent. If interspecific competition with $P$. cinctipes was responsible for the upper limit of $P$. eriomerus, one would expect to see this species shift its niche higher in the absence of its congener, as has been observed in other 'natura]' experiments (Diamond 1978). The differences in the upper limit of $P$. eriomerus among Clallam Bay, Seattle, and Bamfield are probably due to differences in the tidal regimes at these 3 locations, specifically tidal amplitude. Comparing the number of aerial exposures experienced by a $P$. eriomerus living at the upper limit of its distribution in each of these locations (Fig. 13) reveals that a crab at Clallam Bay is exposed roughly twice as often as its conspecifics in Bamfield, approximately $60 \mathrm{~km}$ away. Clearly, a comparison of average exposure times per month will yield very different results for these areas, but such a comparison may not be biologically meaningful. However, if $P$. eriomerus has a physiological limitation related to exposure (e.g. susceptibility to

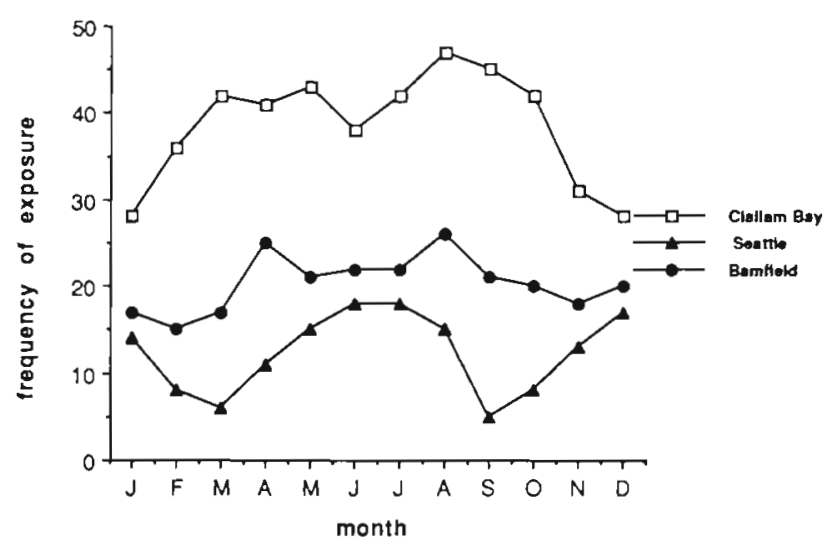

Fig. 13. Frequency (number) of aerial exposures for a Petrolisthes eriomerus living at the upper limit of its distribution in each of 3 locations 
Table 2. Estimated maximum exposure time (lowest predicted summer tide) for a Petrolisthes eriomerus living at the upper limit of the species' distribution in 3 areas (see Fig. 1)

\begin{tabular}{|lc|}
\hline Location & $\begin{array}{c}\text { Maximum time } \\
\text { (h:min) }\end{array}$ \\
\hline Clallam Bay & $6: 10$ \\
Vashon Island & $4: 28$ \\
Diana Island & $4: 53$ \\
\hline
\end{tabular}

desiccation or high temperature) then the critical factor would be associated with periods of continuous emersion (Doty 1946, Swinbanks 1982) rather than frequency or average number of hours exposed per month. Greater tidal amplitude results in longer exposures at a given absolute tidal level, and the common factor among these areas is a maximum exposure time of 4 to $6 \mathrm{~h}$ (Table 2). Although continuous exposure time is somewhat longer at Clallam Bay, deleterious effects are probably mitigated somewhat both by the nearly constant swell that this area receives and by the unusually heavy growth of macroalgae present during summer months, features not present at the other locations

\section{Upper limit of Petrolisthes eriomerus}

The failure of Petrolisthes eriomerus to exploit higher tidal levels in the absence of its congener, coupled with its inability to survive when transplanted, strongly suggests that this species is physiologically limited to the lower intertidal. Zitten (1979) also found that $P$. eriomerus was unable to survive when transplanted as little as $0.3 \mathrm{~m}$ above its observed distribution, and noted during dive transects that the same zonation patterns persisted throughout the tidal cycle.

One potentially limiting factor is susceptibility to desiccation. Differences both in tolerance to desiccation (Young 1978) and permeability of the exoskeleton to water vapor (Herreid 1969b) have been found in comparisons of high and low intertidal crabs, so a substantial difference between Petrolisthes cinctipes and $P$. eriomerus in either rate of or tolerance to desiccation could account for their differences in distribution. No such differences were evident, however, and this is perhaps not surprising in light of their behavior. Neither species has been observed to be active or exposed in situ at low tide, and captive specimens subjected to artificially produced low tides always remained immobile both in the light and under a dim red light at night. Since humidity under intertidal rocks tends to remain high (Newell 1979), desiccation is probably not a significant threat to those with adequate shelter. Smaller crabs tended to lose water at a faster rate than larger ones, a relationship previously described for Petrolisthes elongatus in New Zealand (Jones \& Greenwood 1982) and a consequence of their greater surface area relative to body volume (Pellegrino 1984). Therefore an additional, albeit circumstantial, point of evidence that desiccation is not responsible for the upper limit of $P$. eriomerus is the presence of small individuals up to the borderline of the species distribution.

The dramatic difference in thermal tolerance during aerial exposure strongly suggests that the upper limit of Petrolisthes eniomerus is determined by temperature during extreme low-tide periods. At $25^{\circ} \mathrm{C}$ large $P$. eriomerus were moribund within 10 to $15 \mathrm{~min}$, while $P$. cinctipes appeared healthy and responsive after $24 \mathrm{~h}$ at this temperature. In sharp contrast, $P$. eriomerus that were fully submerged at $25^{\circ} \mathrm{C}$ showed no signs of distress; in fact both species were observed filter-feeding during the course of the experiment. An unexpected result was the greater resistance to emersion at $25^{\circ} \mathrm{C}$ by small $P$, eriomerus, with the smallest specimen tested surviving the duration of the experiment.

Crab habitat temperatures were measured in situ during a period when hot weather coincided with extremely low tides. By placing the bulb of a mercury thermometer in contact with crabs beneath rocks, temperatures as high as $17^{\circ} \mathrm{C}$ were found at the transition zone, $19^{\circ} \mathrm{C}$ under rocks in the Petrolisthes cinctipes zone, and from 24 to $28^{\circ} \mathrm{C}$ among $P$. cinctipes in mussel beds. The latter temperature would be lethal to $P$. eriomerus within minutes, and $17^{\circ} \mathrm{C}$ at the borderline would result in severe stress and possibly death. In retrospect, a better approach to the thermal stress experiments would be a comparison of the time required for crabs to recover from exposure to elevated temperatures, such as elapsed time before resumption of filter-feeding. Our experiences with thermally stressed $P$. eriomerus indicate that many, while still meeting the criteria for 'alive' in the above experiment, do not recover when placed back in water.

In light of the above experiments, the temperatures observed in the field, and the results of the sampling distributions, it is reasonable to assume that the upper limit of the distribution of Petrolisthes eriomerus is in part, if not wholly, determined by its inability to withstand elevated temperatures during periods of emersion. If this is the case, should one expect mass mortalities when extremely low tides coincide with high temperatures? While possible in some instances, we suspect this is relatively rare. Extreme low tides are not. a sudden event, and individuals near the upper limit would be subject to increasing stress for several days before the lowest tide. Barring sudden changes in the 
weather, the crabs would probably have ample warning and move down the tidal gradient in response.

The actual cause of mortality is not yet known, but the dramatic size effect and resistance to elevated temperatures when submerged is suggestive of respiratory failure during aerial exposure. These species would be very valuable for comparative physiological studies. $P$. cinctipes displays a stereotyped series of behaviours during aerial exposure, initially recirculating branchial water over reticulated branchiostegites in a manner remarkably similar to that described for brachyurans (Warner 1977. Hawkins \& Jones 1982). Eventually all scaphognathite movement stops, and the rear of the carapace is elevated in such a manner that the posterior gills are readily visible. Finally, the carapace is tightly closed and if undisturbed the crab will remain motionless for hours. In addition, this species has membranous 'windows' on the merus of each walking leg resembling the respiratory structures of some tropical ocypodids (Maitland 1986); however, in limited experiments, we have not found any evidence to date of a similar function in $P$. cinctipes.

\section{Lower limit of Petrolisthes cinctipes}

The Petrolisthes cinctipes transplanted to lower levels all survived and appeared healthy, and transplanted postlarvae grew at the same rate as controls caged within the normal level. While it is possible that longer confinement at the lowel level could change these results, it appears unlikely. We have maintained $P$. cinctipes fully submerged in aquaria for over 2 yr with no visible ill effects, and Zitten (1979) also reported that $P$. cinctipes survived and grew when transplanted to lower, even subtidal, levels and that eggs appeared to develop normally. These results suggest that $P$. cinctipes does not require regular periods of emersion, and that some factor other than a physiological need for exposure must be responsible for its lower limit.

A biotic factor that could affect the distribution of Petrolisthes cinctipes is greater susceptibility to a lowintertidal predator, and this was not directly addressed in the present study. Although physiological limitations of predators such as starfish can result in sharply defined lower limits of their prey (Paine 1974), we were unable to identify any potential predator that could so efficiently control only 1 of these 2 nearly identical species.

Because the lower limit of Petrolisthes cinctipes corresponds to the upper limit of $P$. eriomerus, one promising hypothesis is that competitive interactions with its low-intertidal congener are responsible for the observed patterns. Both species are dependent upon space under large rocks, and would appear to have similar requirements for filter feeding. With little or no direct evidence such competitive exclusion has often been invoked as a causal mechanism to explain distributions (e.g. Jensen 1989); however, it is well documented in crayfish (Bovbjerg 1970) and plays a role in the distribution of amphipods (Grant 1981), hermit crabs (Bertness 1981), grass shrimp (Thorpe 1976), and fiddler crabs (Teal 1958). If competitive interactions alone determine the lower limit of $P$. cinctipes it would provide a parsimonious explanation for the described zonation.

Competition experiments are inherently difficult to conduct, and many factors including size (Bovbjerg 1956), sex (Sinclair 1977), molt stage (Tamm \& Cobb 1978), food availability (Hazlett et al. 1975), and previous experience (Hazlett 1966) can affect the aggressiveness of a crustacean and possibly influence the outcome of a contest. It is difficult to control for all possible variables, but if the sharply defined lower limit of Petrolisthes cinctipes is solely due to competitive interactions with its congener, than a clear pattern of dominance by $P$. eriomerus should have been apparent. This was not the case, since $P$. cinctipes was clearly the dominant competitor beneath the concrete blocks. This agrees with the findings of Zitten (1979), who combined the 2 species and observed their distribution on the underside of a concrete patio block. He reported that $P$. cinctipes won a high proportion $(77 \%)$ of the interspecific contests observed and occupied a disproportionately large area of the block, and concluded that the lower limit of this species could not be due to competitive interactions with its congener. Since space under blocks was not limited in our experiment competition was for high-current feeding locations; nevertheless, the extremely poor showing by $P$. eriomerus makes competitive exclusion of $P$. cinctipes seem unlikely. Although it is possible that passive feeding locations are a resource of less importance to this species, dominant male $P$. eriomerus vigorously attempted to defend the spaces and lost consistently. Interestingly, both species have a similar repertoire of intraspecific communicatory and agonistic behaviors (Molenock 1976), and these appear to function in interspecific interactions as well.

When the only available shelter was resting on sand, Petrolisthes cinctipes was less successful at dislodging established $P$. eriomerus and dominating the space than in the previous experiment. Yet under these conditions it was just as effective at winning space as newly introduced $P$, eriomerus, making it appear highly unlikely that competitive exclusion alone accounts for its absence from the low intertidal. As stated before, $P$. eriomerus would have to be over- 
whelmingly dominant for competition to account for the sharp delineation of the $P$. cinctipes lower limit, and there was no suggestion of such dominance in these or Zitten's (1979) experiments.

Further evidence that the lower limit is not due to competitive interactions comes from enclosure experiments conducted by Zitten (1979) in the field. In these, elongate enclosures ('runs' constructed from plastic herring roe baskets and nylon fish net) were placed on the beach with their midpoints corresponding to the borderline between the 2 species. In single-species runs Petrolisthes cinctipes did not select for tide height, while $P$. eriomerus moved to the lower ends; when the 2 were mixed $P$. cinctipes continued to utilize entire runs. This, combined with Zitten's competition experiments, led him to conclude that $P$. cinctipes is not excluded from the lower intertidal by its congener, but he was at a loss for an alternative explanation for its limited distribution. Here we propose that the primary factor limiting the distribution of $P$. cinctipes is composition of the substrate.

A number of authors have suggested that substrate composition is responsible for various observed distributions of crabs, either as it relates to feeding methods (Griffin 1971, Iceley \& Jones 1978), burrowing activity (Jones 1972, Ringold 1979, Menendez 1987) or a combination of these (Hawkins \& Jones 1982). Field experiments to address substrate effects would be especially difficult with taxa such as ghost or fiddler crabs, because they often forage over large areas and utilize different areas of the beach depending on the time of day. Ocypodids also rely heavily on their burrows for protection from thermal stress (Powers \& Cole 1976, Macintosh 1978), and it is possible that transplanted individuals could die before completing construction of a burrow. Species that utilize existing shelter such as shell or rock are thus more amenable to this type of experimental manipulation, porcelain crabs in particular because of their filter-feeding habits.

Transplanted Petrolisthes cinctipes confined with patio blocks were physically separated from the substrate by the cage material. Similarly, Zitten's (1979) enclosures also prevented contact with the underlying sediment and thus tested for choice of tidal exposure only. The sediment sampling results indicated that vertical distribution of $P$. cinctipes was correlated with composition of the sediment underneath the rocks, the sediment change being coincidental with the upper limit of $P$. eriomerus. The striking zonation at Neah Bay corresponded to a similar abrupt physical change in the beach, while at Dixon Island this abrupt change occurred just below the upper limit of $P$. eriomerus, resulting in a slight overlap of the 2 species. At the Bamfield Marine Station foreshore and Kelp Bay this substrate transition did not occur intertidally and there was a large overlap in the vertical distribution of these species; during an extremely low tide large numbers of $P$. cinctipes were found alongside $P$. eriomerus and such typically subtidal organisms as the cup coral Balanophyllia elegans and the lithodid Phyllolithodes papillosus. The natural occurrence of $P$. cinctipes in the low intertidal confirms that regular emersion is not a physiological requirement, and suggests that predation and competition are not the primary determinants for the zonation pattern.

The result of the field manipulation of sediment composition beneath rock piles indicates that Petrolisthes cinctipes actively avoid areas where a high proportion of sand is present. This was apparent even within treatment patches since much of the variability in these areas was due to inundation of some sections with sand. Specimens placed in the lower half of control patches either tended to move higher up the beach within their patch or emigrated to adjacent treatment patches, and were surprisingly mobile since some of the tagged crab were recovered as far as 10 to $12 \mathrm{~m}$ from their starting point.

In the field Petrolisthes cinctipes avoided rocks that rested on sand, yet in captivity readily hid beneath slate plates resting on sand, as evidenced in the competition experiment. This difference may be linked to filter-feeding behavior and the physical environment. In addition to filling in spaces beneath rocks, sand and silt resuspended by wave surge undoubtedly interfere with filter-feeding, a situation not encountered under relatively static laboratory conditions. But if suspended sediment interferes with filter-feeding in $P$. cinctipes, what effect does it have on $P$. eriomerus? A possible explanation for different tolerances to sediment load may lie in comparative morphology. Both species have dense pads of plumose setae on their chelipeds that are used to gather food from surfaces; these pads are highly developed in $P$. eriomerus but relatively small in $P$. cinctipes. Gabaldon (1970) described this alternative feeding method for $P$. cabrilloi, noting both that this species had the largest pads of any species of Petrolisthes in California and also that it lived in muddier areas than other porcellanids. She suggested that this mode of feeding is used when suspended sediment hampers ordinary filter-feeding; likewise, it is possible that the larger pads of $P$. eriomerus reflect a greater dependence on this alternative method and allow it to use habitat unsuitable for $P$. cinctipes. If true, this situation may be somewhat analogous to that described by Felgenhauer \& Abele (1983) for atyid shrimp, where the dominant competitor for space is limited in distribution by its need to passively filter-feed. Unlike this shrimp, however, the fundamental niche (Colwell \& Fuentes 1975) of $P$. cinctipes is not fully contained within that of $P$. eriomerus. Because of the apparent 
intolerance of $P$. cinctipes to fine sediments and the limited intertidal distribution of $P$. eriomerus, areas of potential competition are fairly rare. $P$. cinctipes is one of the most abundant macroscopic invertebrates living in the interstices of Mytilus californianus beds, occurring in densities up to $3933 \mathrm{~m}^{-2}$ (Jensen 1990). Here they are well protected and subject to ample water motion in an area relatively free of sediment. Perhaps $P$. cinctipes is best considered a Mytilus-bed specialist that exploits similar sediment-free space when it is available beneath rocks.

In summary, the zonation patterns observed for these 2 species are apparently more a passive consequence of physiological limitations and substrate preferences than the result of continuing biotic interactions. Habitat suitable for both species appeared to be relatively rare, and when it did occur they appeared capable of coexisting. Finally, highly conservative gregarious settlement behavior exhibited by the megalopae of both species (Jensen 1989) helps to maintain existing patterns.

Acknowledgements. We are grateful to Lydia Carroll, Brett Dumbauld, Don Levitan, Donna Morton, and Nancy Sanders for their assistance in the field work, and also thank the staff of the Bamfield Marine Station. A portion of this work was supported by the Washington Sea Grant Program (NA-86AAD-SG044, project R/F-68). Contribution No. 333 of the School of Fisheries, University of Washington.

\section{LITERATURE CITED}

Abrams, P. A. (1987). Resource partitioning and competition for shells between intertidal hermit crabs on the outer coast of Washington. Oecologia 72: 248-258

Bertness, M. D. (1981). Competitive dynamics of a tropical hermit crab assemblage. Ecology 62: 751-761

Bovbjerg. R. V (1956). Some factors affecting aggressive behavior in crayfish. Physiol. Zool. 29: 127-136

Bovbjerg, R. V (1970). Ecological isolation and competitive exclusion in two crayfish (Orconectes virilis and Orconectes immunis). Ecology 51: 225-236

Burggren, W W., McMahon, B. R. (1981). Oxygen uptake during environmental temperature change in hermit crabs: adaptation to subtidal, intertidal, and supratidal habitats. Physiol. Zool. 54: 325-333

Burnett, L. E. (1988). Physiological responses to air exposure: acid-base balance and the role of branchial water stores. Am. Zool. 28: 125-135

Burnett, L. E., McMahon, B. R. (1987). Gas exchange, hemolymph acid-base status, and the role of branchial water stores during air exposure in three littoral crab species. Physiol. Zool. 60: 27-36

Colwell, R. K., Fuentes, E. R. (1975). Experimental studies of the niche. A. Rev. Ecol. Syst. 6: 281-310

Connell, J. H. (1961). Effects of competition, predation by Thais lapillus, and other factors on natural populations of the barnacle Balanus balanoides. Ecol. Monogr 31: 61-104

deFur, P. L. (1988). Systemic respiratory adaptations to air exposure in intertidal decapod crustaceans. Am. Zool. 28: $115-124$

deFur, P. L., McMahon, B. R., Booth, C. E. (1983). Analysis of hemolymph oxygen levels and acid-base status during emersion 'in situ' in the red rock crab, Cancer productus. Biol. Bull. mar biol Lab., Woods Hole 165: 582-590

dePledge, M. H. (1984). The influence of aerial exposure on gas exchange and cardiac activity in the shore crab. Carcinus maenas (L.). Comp. Biochem. Physiol. 79A: 339-344

Diamond, J. M. (1978). Niche shifts and the rediscovery of interspecific competition. Am. Scient. 66: 322-331

Doty, M. S. (1946). Critical tide factors that are correlated with the vertical distribution of marine algae and other organisms along the Pacific Coast. Ecology $27 \cdot 315-328$

Edney, E. B. (1961). The water and heat relationships of fiddler crabs (Uca spp.). Trans. R. Soc. S. Afr. 36: 79-91

Engstrom, N. A. (1984). Depth limitation of a tropical intertidal xanthid crab, Cataleptodius floridanus, and a shallowwater majid, Pitho aculeata: results of a caging experiment. J. crust. Biol. 4: 55-62

Felgenhauer, B. E., Abele, L. G. (1983). Ultrastructure and functional morphology of feeding and associated appendages in the tropical fresh-water shrimp Atya innocous (Herbst) with notes on its ecology. J. crust. Biol. 3: 336-363

Gabaldon, D. J. (1970). Observation of a possible alternate mode of feeding in a porcelain crab (Petrolisthes cabrilloi Glassell, 1945) (Decapoda, Anomura). Crustaceana 36: $110-112$

Grant, J. (1981). Dynamics of competition among estuarine sand-burrowing amphipods. J. exp. mar Biol. Ecol. 49: $255-265$

Gray, I. E. (1957). A comparative study of the gill area of crabs. Biol. Bull. mar biol. Lab., Woods Hole 112: 34-42

Griffin, D. J. G. (1971). The ecological distribution of grapsid and ocypodid shore crabs (Crustacea: Brachyura) in Tasmania. J. Anim. Ecol. 40: 597-621

Hawkins, A. J. S., Jones, M. B. (1982). Gill area and ventilation in two mud crabs, Helice crassa Dana (Grapsidae) and Macrophthalmus hirtipes (Jacquinot) (Ocypodidae), in relation to habitat. J. exp. mar. Biol. Ecol. 60: 103-118

Hazlett, B. A. (1966). Factors affecting the aggressive behavior of the hermit crab Calcinus tibicen. Z. Tierpsychol. 6: $655-671$

Hazlett, B. A., Rubenstein, D., Rittschof, D. (1975). Starvation, energy reserves, and aggression in the crayfish Orconectes virilis (Hagen, 1870) (Decapoda, Cambaridae). Crustaceana 28: 11-16

Herreid, C. F. (1969a). Water loss of crabs from different habitats. Comp. Biochem. Physiol. 28: 829-839

Herreid, C. F. (1969b). Integument permeability of crabs and adaptation to land. Comp. Biochem. Physiol. 29: 423-429

Hiatt, R. W. (1948). The biology of the lined shore crab, Pachygrapsus crassipes Randall. Pacif. Sci. 2: 135-213

Icely, J., Jones, D. (1978). Factors affecting the distribution of the genus Uca (Crustacea: Ocypodidae) on an East African shore. Estuar. coast. mar Sci. 6: 315-325

Jensen, G. C. (1989). Gregarious settlement by megalopae of the porcelain crabs Petrolisthes cinctipes (Randall) and $P$. eriomerus Stimpson. J. exp. mar Biol. Ecol. 131: 223-231

Jensen, G. C. (1990). Intertidal zonation of porcelain crabs: resource partitioning and the role of selective settlement. Ph.D. dissertation, University of Washington, Seattle

Johnson, I., Uglow, R. F. (1985). Some effects of aerial exposure on the respiratory physiology and blood chemistry of Carcinus maenas (L.) and Liocarcinus puber (L.). J. exp. mar. Biol. Ecol. 94: 151-165

Jones. D. A. (1972). Aspects of the ecology and behavior of 
Ocypode ceratophthalmus (Pallas) and $O$. kuhlii de Haan (Crustacea: Ocypodidae). J. exp. mar Biol. Ecol. 8: 31-43

Jones, M. B., Greenwood, J. G. (1982). Water loss of a porcelain crab, Petrolisthes elongatus (Milne Edwards, 1837) (Decapoda, Anomura) during atmospheric exposure Comp. Biochem. Physiol. 72A: 631-636

Macintosh, D. J. (1978). Some responses of tropical mangrove fictdler crabs (Uca spp.) to high environmental temperatures. In: McLusky, D. S., Berry, A. J. (eds.) Proceedings of the 12th European Marine Biology Symposium Pergamon Press, Oxford, p. 49-56

Maitland, D. P. (1986). Crabs that breathe air with their legs Scopimera and Dotilla. Nature, Lond. 319: 494-495

Menendez, R. J. (1987). Vertical zonation of the xanthid mud crabs Panopeus obesus and Panopeus simpsoni on oyster reefs. Bull. mar. Sci. 40: 73-77

Molenock, J. (1976). Agonistic interactions of the crab Petrolisthes (Crustacea, Anomura). Z. Tierpsychol. 41. 277-294

Newell, R. C. (1979). Biology of intertidal animals, 3rd edn. Marine Ecological Surveys Ltd. U.K.

NOAA (1989). High and low water predictions: west coast of North and South A.merica, including Hawaiian Islands. National Ocean Service, Rockville, MD

Nyblade, C. F. (1974). Coexistence in sympatric hermit crabs Ph.D. dissertation, University of Washington, Seattle

Paine, R. T. (1974). Intertidal community structure. Experimental studies on the relationship between a dominant competitor and its principal predator. Oecologia 15: 93-120

Pellegrino, C. R. (1984). The role of desiccation pressures and surface area/volume relationships on seasonal zonation and size distribution of four intertidal decapod Crustacea from New Zealand. implications for adaptation to land. Crustaceana 47: 251-268

This article was submitted to the editor
Posey, M. H. (1986). Predation on a burrowing shrimp: distribution and community consequences. J. exp. mar. Biol Ecol. 103: 143-161

Powers, L. W., Cole, J. F. (1976). Temperature variation in fiddler crab microhabitats. J. exp. mar. Biol. Ecol. 21. $141-157$

Ringold, P. (1979). Burrowing, root mat density, and the distribution of fiddler crabs in the eastern United States J. exp. mar. Biol. Ecol. 36: 11-21

Sinclair, M. (1977). Agonistic behavior of the stone crab, Menippe mercenaria (Say). Anim. Behav. 25: 193-207

Swinbanks, D. D. (1982). Intertidal exposure zones: a way to subdivide the shore. J. exp. mar. Biol. Ecol. 62: 69-86

Tamm, G. R., Cobb, S. (1978). Behavior and the crustacean molt cycle: changes in aggression of Homarus americanus. Science 200: $79-81$

Teal, J. M. (1958). Distribution of fiddler crabs in Georgia salt marshes. Ecology 39: 185-193

Thorpe, J. H. (1976). Interference competition as a mechanism of coexistence between two sympatric species of the grass shrimp Palaemonetes (Decapoda: Palaemonidae), J. exp. mar. Biol. Ecol. 25: 19-35

Truchot, J. P. (1975). Blood acid-base changes during experimental emersion and reimmersion of the intertidal crab Carcinus maenas (L.). Respir. Physiol. 23: 351-360

Warner, G. F. (1.977). The biology of crabs. Van Nostrand Reinhold Company, New York

Young, A. M. (1978). Dessication tolerances for three hermit crab species Clibanarius vittatus (Bosc), Pagurus pollicaris Say and $P$. longicarpus Say (Decapoda, Anomura) in the North Inlet Estuary, South Carolina, USA. Estuar coast. mar Sci. 6: 11.7-122

Zitten, D. (1979). Factors influencing the vertical distributions of two intertidal porcelaun crab populations. Ph.D. dissertation, University of British Columbia, Vancouver

Manuscript first received: January 14, 1991

Revised version accepted: April 4, 1991 